\title{
6
}

\section{From the land to the sea: Christianity, community and state in Fiji-and the 2014 elections}

\author{
Lynda Newland
}

\section{Introduction}

Much has changed since I left Fiji in December 2012, at a time when the Yash Ghai constitution was rejected by the government. A group led by the attorney-general, Aiyaz Sayed-Khaiyum, drew up a new constitution, notable for its affirmation of secularism, in 2013. The then president of the Methodist Church, Tuikilakila Waqairatu, began a review of the Methodist constitution to ensure that the church could not be used as a vehicle for political mobilisation, but passed away six months after his ordination in February 2014 (Rasoqosoqo 2013, 2014; Tawake 2013). In the lead-up to the general elections, Waqairatu's successor, Tevita Nawadra Banivanua, affirmed that ministers of the Methodist Church could no longer participate in politics without resigning from their positions (Talebula 2014). Outside the Methodist Church, debate about the significance of secularism for Fiji began to flow freely, reflected in an explosion of postings in the social media and Internet services, despite the restrictions on 
the regular media. The victory by Voreqe (Frank) Bainimarama and his FijiFirst party ensured that secularism in one of its forms was institutionalised, guaranteed by the Constitution.

In effect, the 2014 elections marked a threshold to a potentially radical transformation in the style of Fiji governance that the military government has developed since the 2006 coup. At the same time, the leadership of the Methodist Church, a key institution in which ethnic and religious nationalism has flourished in the past, has undertaken reforms begun by Waqairatu. In this chapter, I explore the religious climate in which Fiji's 2014 elections took place; and, in particular, I chart the relationship between the Bainimarama Government, the Methodist Church, and some of the other Christian churches to show the evolving politics of religion in Fiji. In doing so, I note the way the vanua (land and community) has come to be used in contemporary rhetoric; the continuing use of the motif of Exodus to describe Methodist Taukei experience, albeit in a theology that is shifting from the land (vanua) to the ocean (moana); and the fact that, although Christianity is diverse in Fiji, many Taukei Christians share conceptions about an active relationship between the Taukei community, church and the state. ${ }^{1}$

\section{The Methodist Church of Fiji and the military government}

At least since 1987 and until around 2009, the Methodist Church of Fiji represented the interests of a powerful section of the Taukei across most of the country. Broadly, these interests are commonly encapsulated in the formula known as 'the three pillars': lotu (denoting 'religion', particularly Methodism), matanitu (government and/or chiefly system) and vanua (the land and community) (Niukula 1994). Lotu and vanua are joined in idioms such as the nationalist maxim, Noqu Kalou, noqu vanua (My God, my land) (Ryle 2010; Tuwere 2002). The connection between God and the land is entrenched in the village

1 'Taukei' and 'Indo-Fijian' are the terms chosen for this publication. In 2010, it was decreed that indigenous Fijians be referred to as iTaukei (for its implications, see Newland 2013). The descendants of indentured labourers and other immigrants from India have variously been called Indo-Fijians and Fiji Indians, and since 2010 have been considered Fijians, but all these terms are inconsistently used, depending on the speakers and their contexts. 
system, in which over half the Taukei population continue to live (Fiji Bureau of Statistics 2007). ${ }^{2}$ Saturated with associations with land, the concept of vanua also signifies a community unified through kin ties and marriage rules, and connected with the land through kava ceremonies, agriculture and death rites.

From an early stage in the colonial history of Fiji, the church structure grew rather like a rhizome - from cell groups into districts under a connexional government (Baleiwaqa 2003), challenged only by the ancestral gods and Roman Catholicism, the latter which initially had little success (Kelly 1945). As the connexional government grew, Taukei nationalism was expressed through narratives about ancestral genealogies that came to be called the Kaunitoni Migration, and dissent from cult figures outside the church such as Navosavakadua and Apolosi Nawai, and their followers, who the colonial government frequently exiled and deported to other islands.

The Methodist Church of Fiji remained under British and then Australian administrative responsibility until the 1960s, when the administration was localised and the first local president appointed. As Taukei began to move towards the urban areas, the Methodist Church became the space in which politics were discussed (Halapua 2003). At the same time, indigenisation of the church was encouraged to reflect Taukei values and understandings of Christianity rather than Australian or European interpretations and despite the fact that the church also had an Indian Division (Tippett 1980). Although this indigenisation of the church aimed towards postcolonial self-determination, it also created the conditions through which conservative and traditionalist Taukei values would come to be used to mobilise support for the Taukei elite.

For the 20-year period after the church's independence in 1964, the presidents of the Methodist Church were moderates who endorsed ecumenism and multiracialism. They seemed to reflect a liberal mood in the church, to the extent of electing an Indo-Fijian president in 1977 (Weir 2015, p. 66). However, influenced by the politician Sakeasi

2 These figures are contentious given that the urban/rural divide is not clear in Fiji because many Taukei live in villages even within urban centres; mobility between rural villages and urban centres is high; local observations suggest that urbanisation has increased in the years since the 2007 census; and most Taukei identify themselves as belonging to the village of their ancestors even if they have not returned there for several generations. 
Butadroka, and legitimated largely in relation to the strengthening political and demographic position of the Indo-Fijian population, Taukei nationalism grew increasingly strident. As has now been extensively documented, in 1987 Sitiveni Rabuka, a military colonel, overthrew the newly elected Indo-Fijian-dominated government led by Dr Timoci Bavadra, a Taukei commoner. Reverend Manasa Lasaro, a nationalist Methodist minister, led a parallel coup in the church and persuaded Rabuka to enact a Sunday ban that prohibited all commercial activities on Sundays, reflecting a transition to a particular kind of Christian state. Although the Sunday ban was eventually lifted, Rabuka became the Prime Minister of Fiji under the Constitution adopted in 1990 (e.g. Ernst 2004; Garrett 1990). He governed until 1999, when he lost the elections to the Indo-Fijian trade unionist, Mahendra Chaudhry.

Nationalist Taukei concerns centred on the theme of losing the land and with it the Taukei community's place in the world. The threat of losing the land was largely a fiction because Taukei land ownership was protected in the Constitution; but the idea of loss, combined with the two-fold meanings of vanua as land and community resonated deeply with many Taukei communities. Moreover, such concerns were preached from the pulpit in a direct analogy with the biblical teachings of Exodus and God's promise of land. One investigative documentary of the period shows Rabuka in his role as lay preacher, preaching both in English and Fijian from the book of Jeremiah:

The words of Jeremiah the prophet, Lamentations Chapter 5. Remember oh Lord, what has happened to us. Look at us and see our disgrace. Our property is in the hands of strangers. Foreigners are living in our homes. Our fathers have been killed by the enemy and now our mothers are widows. Driven hard like donkeys or camels we are tired but are allowed no rest. (Rabuka in Walmsley 1987)

The use of Jeremiah reinforced the connection between lotu and vanua in a prophecy of loss - and, although land was a central concern, the prophecy was also about community and its relationship with God. ${ }^{3}$ Implicit in the suggestion of community was the sense of an upset to Taukei tradition involving the correct ordering of the 'three pillars' of

3 Tomlinson discusses the Taukei sense of loss and diminishment in relation to the concept of mana on the island of Kadavu (Tomlinson 2006). In Suva, loss and diminishment has been associated directly with racial relations and contestation for political power and land. 
Taukei society between vanua, lotu and matanitu. This order includes ideas about clear hierarchies from chiefs and churchmen down to the husbands and fathers of households; and about the attainments of a masculinity linked with a romanticised notion of the physicality of the Taukei warrior past and expressed through the kava ceremony, rugby and the norms of the patriarchal Methodist family, including adult heterosexuality and the obedience of wives and children to husbands, fathers and chiefs. In Rabuka's rhetoric, all this was threatened by a multiracial and multi-religious society.

A businessman, George Speight, led the next coup in 2000. While race was obviously a major issue, the 2000 coup also reflected the tensions between Taukei Christian churches, clans and institutions across Fiji. In response, the Methodist Church met with a number of Pentecostal churches after the coup to unify Fijians under an umbrella organisation called the Assembly of Christian Churches in Fiji (ACCF), with the vision of creating a Christian state (Newland 2006; 2007). In the ACCF version, Fiji is represented as a possession of God that would be treasured if ACCF members honoured and glorified Him by uniting and living in a correct relationship with Him (which is perceived in terms of loving and fearing God and being prepared to reconcile with each other) (Newland 2007, p. 306). Those who were not Christians were to be tolerated, providing they also lived by Christian values and acknowledged that they were guests in a Taukei country. Two implications of this theology stand out: the idea that the vanua was no longer simply a network of kin in a specific geographical area but was now considered concomitant with the nation-state of Fiji; and the legitimation of a racial hierarchy within Fiji in which Taukei continued to have paramountcy. Despite a greater tolerance of other races than was expressed in 1987, the ACCF leadership did not aspire towards any form of equity or equality with Hindu and Muslim Indo-Fijians, many of whom descended from the indentured labourers brought out from India in the 19th century. Likewise, secularism was not viewed as neutral because it challenged the Taukei nationalist ideas of paramountcy. This was legitimated by the notion that, if society is secular, God is absent (cf. Weir 2015).

In 2009, the Constitution was abrogated for the third time in 20 years, ostensibly to make way for the military's large-scale political, economic and social transformations. Three years later, a constitution commission led by academic Professor Yash Ghai wrote a draft constitution based 
on submissions from across Fiji. ${ }^{4}$ While moderate Taukei argued for the retention of a Christian identity that tolerated others, many of the Taukei submissions showed a desire for a Christian state based on the patriarchal family form and on the continuation of Taukei paramountcy within the nation-state (Newland 2013). Although this was clearly an aggravation for Bainimarama and his government, the reasons the draft constitution ultimately proved unacceptable were because it required the Bainimarama Government to step down six months before the elections, it did not grant full and unconditional immunity, and court proceedings begun before interference from the regime could be revived (Narsey 2013).

In the meantime, the Bainimarama Government had begun court proceedings against the Methodist leaders, including the then president Tuikilakila Waqairatu and three former presidents well known for their ethno-religious nationalist inclinations: Ame Tugawe, Tomasi Kanailagi and Manasa Lasaro. They were charged for holding a meeting allegedly in breach of the Public Emergency Regulation in 2009. Where the position of various leaders of the Methodist Church had been ambiguous throughout 2012, Waqairatu realised that he had to counter the repressive tactics of the Bainimarama Government to avoid the church being deregistered. He began a review of the Methodist Church's constitution, which included the conditions that ministers must resign in order to contest elections and that no support for any coup would be tolerated (Rasoqosoqo 2013). From then on, Banivanua appeared in the media regularly to confirm that the Methodist Church would no longer play a political role or be aligned to any political party but would focus on the spiritual life of its members, family support groups and education. The church circuits were directed to avoid politics and to uphold the principle that church members had the right to join any political party. Church ministers who wanted to stand at the elections would be asked to resign but could reapply if they did not succeed at the elections (e.g. Bolatiki 2013; Tawake 2013). This attempt to engineer a massive top-down shift in Methodist nationalist thought failed to halt the court case, which was still in process in 2014 when Waqairatu passed away (Kate 2014).

4 For a discussion of this Constitution, see Kant \& Rakuita 2014. 
Although the church appeared to fully concede to the military government's demands, it was reported that 'while the church would be apolitical, they would make comments on some political decisions that affect the church' (Bolatiki 2013). In the lead-up to the 2014 elections, Banivanua confirmed in an interview that the church had to accept that Fiji was now defined as a secular state, but stated that they would continue to pursue their Christian principles in relation to the way that they viewed the governing of Fiji (Radio New Zealand 2014). These comments show that, despite the move away from direct political action, the leaders of the Methodist Church in Fiji continue to regard themselves as legitimate voices of 'the people' and in particular their congregations (which are predominantly Taukei), and therefore that they have a role in representing them in the political domain. On this point, the Methodist Church does not stand alone. As will become evident, many Christian churches share this idea. In fact, elsewhere, particularly among the priests and ministers who follow liberation theology from the Roman Catholic Church and the Presbyterian Church, it is termed 'the prophetic voice' (Newland 2006).

\section{Religious advice to voters}

In the lead-up to the 2014 elections, several churches in very different relationships with the government and representing very different interpretations of Christianity were reported as advising their congregations on how to vote, including the Roman Catholic Church in Fiji, the New Methodist Church, and the Seventh Day Adventists (SDA). The leaders of the first two of these churches had close relationships with the Bainimarama Government in the first three years or so after the coup, although for very different reasons (see Newland 2009, 2012). By contrast, in 2005 the general secretary of the SDA, Usaia Baravi, explained to me that the SDA remained completely separate from issues of the state (Newland 2006) - which was possibly a strategy to distance the church from George Speight, the leader of the 2000 coup and a member of SDA. Yet all these churches wanted their adherents to vote for a 'godly' government that would make decisions on the basis of the scriptures - despite the fact that each interprets the scriptures very differently and accords certain parts of the scriptures more important than others. 
After the coup in 2006, the Roman Catholic Church in Fiji supported the military government and participated in its Charter in the hope that this was an opportunity to overturn deep-seated structures in Fijian society: in particular, to neutralise the racist aspects of Taukei religious ethno-nationalism, and to reduce exploitation and poverty, especially for Indo-Fijians who had faced mass expulsion from the land at the end of their tenancies or who made up a significant portion of the working poor (Newland 2009). This focus is consistent with the church's interest in liberation theology, a theology in which political activity is considered justified if it overturns exploitative structures in favour of the poor. However, the church faced some difficult moments when social justice appeared to become expedient to other interests in government decisions, which has given rise to a number of misunderstandings. Within the first year of his ordination, Archbishop Peter Loy Chong showed misgivings about the way the secularism of the Constitution was described in terms of ensuring that religion was a private matter (Chandar 2013). In the lead-up to the 2014 elections, he urged 'Catholics to make informed voting decisions for the betterment of the country' (Swami 2014). According to Chong, the church should be apolitical but also has the responsibility of informing its members to help them make wise decisions 'based on the Scriptures and the teachings of the Church' (Swami 2014). Clearly, Chong was concerned about the balance between church and state; and, in particular, any limitations that might affect Catholic religious practice.

Another church that had taken the stage from 2008 to 2009 was the New Methodist Church, a breakaway from the Methodist Church that quickly became Pentecostal in style. Due largely to the fact that the head of the New Methodist Church, Atunaisa Vulaono, was the brother of the then head of the police force, Esala Teleni, this church became aligned with the state in an attempt to convert the police force to Christianity as part of the fight against crime. For the military government, supporting this church had the advantage of undermining the hegemonic presence and public centrality of the Methodist Church. However, tensions rose over the New Methodist's evangelical activities, such as requiring police to perform on stage as part of its community outreach regardless of whether they were Christian or Hindu, the weekly evangelical sermons in the centre of Suva city, and the fact that a significant amount of the community policing budget 
was spent on these activities. Finally, the New Methodists fell out of favour with the government, but they continue to rally support from the youth (Newland 2012).

In April 2014, the New Methodists held a rally in Labasa that attracted 1,200 members drawn primarily from nine youth groups around the northern islands of Fiji. Vulaono gave a sermon, reminding 'church members of God's place in the September elections' (Taleitaki 2014). The report quotes him as saying:

'We need God before the upcoming elections; every district, province and the nation needs God's judgement as He alone knows best.'

He further said the general election needed God's intervention as He alone knew the future and what was good and best for Fiji.

The nation, he said, needed people to take the nation to greener pastures for the betterment of its people. (Taleitaki 2014)

Vulaono's statement clearly goes much further than asking its adherents to make a decision about voting for political candidates based on whether their policies are consistent with the teachings of the scriptures: it reflects the idea that God stands above the processes of democracy - in a way that does not sound very different from that promoted by the Assembly of Christian Churches in Fiji from 2001 to 2006 (Newland 2007). With God represented as guide and judge, Taukei are likened to the biblical Jews; but, here, God's intervention is required not for personal salvation but to save the nation. Given the intensity of the New Methodist Church's evangelical activity, it is clear that they do not envisage a multi-religious nation-state but one that is wholly converted to Christianity.

The Seventh Day Adventists (SDA) brought 150 female leaders together at a meeting in Suva to offer advice about voting. After being divided into small groups to pray, the women were read a letter from the church head, advising them against voting for relatives or for candidates on the basis of their or their party's work, but rather for the candidate who can champion God's will and ensure God's will is done on earth (FijiLive 2014). They were told to vote according to eight principles, which included striving to elect leaders who are led by God. Candidates who violated biblical commands about life, 
family, marriage and faith should be avoided. All members should vote in order to promote, protect and preserve godly government (FijiLive 2014). The letter continued:

In our day and age, there are many who want to drive the name and message of Christ completely out of the public arena. Voting is an opportunity to promote, protect, and preserve godly government. Passing up that opportunity means letting those who would denigrate the name of Christ have their way in our lives. (FijiLive 2014)

Although SDA is a very different church from the New Methodists and has sought to separate its activities from politics, it is clear that they also seek a government that would promote the presence of Christianity in government, without which the people of Fiji would face a moral void.

While all three churches were advising their members to vote according to the scriptures, their intentions were very different. In the Catholic Church in Fiji, the scriptures were being interpreted from the perspective of liberation theology in an attempt to bring just social structures to the poor without racial prejudice. Secularism was a threat only if it limited the capacity of the church membership to publicly express their religion. By contrast, Vulaono's vision of Fiji is about making Fiji entirely Christian, therefore guaranteeing Taukei privilege - a vision very similar to that of the ACCF. Secularism would inhibit the capacity to evangelise and convert others. The SDA provides a third contrast because, as noted above, it has attempted to avoid any relationship with politics in the past, viewing it as a likely arena for the final deception of Satan (Newland 2006). However, in the lead-up to the 2014 elections, the SDA leadership was clearly seeking a champion of Christianity to reject secularism because it implied a moral void. Although these three visions are very different, the fact that they and possibly many more Christian churches in Fiji do distribute advice on voting shows that they view their churches as a space through which to reflect upon the government under which they live, and are actively working towards a government that reflects the values of these church communities as closely as possible.

Indeed, the Methodist Church was also, rather belatedly, reported as attempting to influence its adherents. After Bainimarama's government won the elections, the Fiji Sun - known to be the mouthpiece for the Bainimarama Government - claimed that a letter had been circulated 
to the divisions of the Methodist Church (with the exception of the Republic of Fiji Military Forces) circuit only a fortnight before the elections, instructing congregations to vote for the predominantly Taukei SODELPA (Social Democratic Liberal Party). According to this report, Iliesa Naivalu, the secretary of the Department of Christian Citizenship and Social Services of the Methodist Church, wrote the letter in Fijian asking the leaders of the division to advise members to 'think before you vote. Don't be swayed by the look of the party and the candidates. Don't be swayed also by the developments carried out and the promises made on what they would do if elected to govern' (Bolatiki 2014). The letter strongly opposed Fiji becoming a secular state instead of a Christian state and asked for the return of the Ghai constitution, which it considered as the voice of the people. It also claimed the church was concerned with the deterioration of the Taukei position in state bureaucracy, including the weakening of Taukei Affairs, the cessation of the Great Council of Chiefs, and changes in leadership and representatives on the Taukei Affairs Board and, finally, the redistribution of scholarships. As many of these issues were the same as those in SODELPA's manifesto, the other major party contesting the elections, Bainimarama accused SODELPA of lying and dictating to congregations what they should believe in (Bolatiki 2014).

Banivanua, now the President of the Methodist Church, responded not by publishing the letter but by posting an open letter on the church's blogsite. ${ }^{5}$ Explaining that he was unaware of the letter's contents until the media response, Banivanua pointed out that the Department of Christian Citizenship and Social Issues was established to provide members with information about the church's position on current issues. The issues raised in the letter were based on resolutions that had been deliberated and voted on at the 2014 Methodist Annual Conference. They needed to be disseminated so that members could reflect on them before they voted. Banivanua further explained that, although Naivalu was writing in a theological context rather than a political and adversarial one, an internal policy for communication

5 Rather strangely to the outsider, the letter begins by welcoming Jewish and Hindu adherents and their festivals. There are very few Jews in Fiji, although a number of Christian sects claim they are descended directly from the Lost Tribes of Israel and many Taukei certainly view the Israelites romantically (see, e.g. Karavaki 2014). The inclusion of both Jews and Hindus in the same welcome suggests that he was welcoming both Taukei and Indians. 
would be introduced (Banivanua 2014a). ${ }^{6}$ He then noted that a policy on multi-faith worship had not yet been developed as the church did not want to compromise on doctrinal beliefs and tradition. He finished with:

The Church is beginning her new exodus, our LakoYani Vou [new Exodus], just as our nation is embarking on a new democracy. Just as we pray for our nation and our government, we seek your prayers for us. (Banivanua 2014a)

By drawing on Exodus and Jeremiah, who also spoke of a new exodus or covenant, Banivanua depicted a new order in which church and state have been separated and in which the leaders and their communities had to find their own ways.

The letter was also posted on Facebook, to which Nikotemo Sopepa, Moderator of the Presbyterian Church of Fiji, replied:

This time-round the church should not be intimidated by the State but speak what is true, what is democratic (voices of the people). I believe the State also needs to be educated on the role of the church in the community. We attend not only to the spiritual welfare of the community we serve, but also the whole sphere of their living (political included). If the church fails to do this, it will lose its calling to serve the community. I agree that Church and State must be separated, but i [sic] totally disagree with the State trying to intimidate the church through/by coercive means - that is not democracy. (Sopepa 2014)

This comment was 'liked' by Pacific Youth Council and Pacific Conference of Churches, among others, and reflects the idea that Christian churches have a role to play as representatives of their communities is widespread among Taukei. Moreover, this role is viewed to be necessarily political, whether that is represented in terms of social justice for the many (the Roman Catholic view) or the legitimation of the moral right of an indigenous community (the nationalist Methodist view).

6 The Methodist leadership had declined an invitation to an Interfaith Thanksgiving Service organised by the PM's Office on the release of the 45 Fijian UN peacekeepers who had been held hostage by an al Qaeda-related organisation. Banivanua explained that, as this service was to be held on the day before the elections, Methodist leaders were concerned because it 'may be construed as a political event' (Banivanua, 2014a). 
However, of concern to any government that attempts to promote a plural society in Fiji, the call for a Christian state or a godly government or even a government based exclusively on Christian principles is also a call for the state to be run by the Taukei and not Hindu or Muslim Indo-Fijians. That almost all Taukei are Christian, that Taukei are a majority in Fiji, and that this Christian message was propagated throughout the Christian churches suggests that this is more than a passing concern.

\section{SODELPA, Christianity and the elections}

Although the leaders of the Methodist Church of Fiji knew that their public face had to be apolitical and that they could not be seen to be aligned with any one political party, political parties did not necessarily share the idea that church and state should be separate. SODELPA, headed by Ro Teimumu Kepa, ${ }^{7}$ represented itself as the legitimate successor of SDL (Soqosoqo Duavata ni Levenivanua or United Fiji Party) - the party that was elected and ousted from government in 2006 (SODELPA 2014a, p. 45). SDL had been sympathetic to the notion that Fiji should be a Christian state and that the Taukei should retain a privileged position in the governance of the state, and SODELPA retained these ideas, although with some contestation from younger members.

In fact, there were at least two contrasting positions on the ideal relationship between church and state in Fiji, both of which have been published on SODELPA's Facebook page. The first, which appeared on 18 July 2014, has been shared and remains there still. In it was a set of bullet points that noted the 2013 Constitution declared Fiji a secular state, which therefore signified the Constitution is a godless Constitution that has ignored the role of Christianity in the development of Fiji (SODELPA 2014b). SODELPA was concerned with the teaching and practice of religious faiths in schools and especially about school prayer and similar controversies about religious devotions during government functions (SODELPA 2014b). When this statement was posted it attracted 24 'likes' and it received another 61 'likes'

7 Ro Teimumu Kepa was Deputy Prime Minister for the SDL government prior to the 2006 coup. She is also paramount chief of the Burebasaga confederacy and Catholic, but retains strong links with the Methodist Church. 
on a shared version. Almost all appeared to be from Taukei. A small number commented that the secular state was the thin end of the wedge and would lead to legalising same sex marriage; that, under Sayed-Khaiyum's influence, the state was becoming Muslim; and that Fiji's situation could be likened to biblical Israel when Muslims demolished the holy temple of Jerusalem. All of these comments reflect views associated with nationalist Taukei Methodism.

A second posting on 22 August reflected a very different perspective. In this posting, the argument made was that:

SODELPA constitution and Manifesto do not call for a Christian State. What we say is that as a government, we will conduct ourselves based on Christian principles and values. These are values shared by all the world's great religions. We are commanded to love our neighbours and do to others as we would have them do to us. We are required to forgive and to be merciful. We must care for the poor, the sick, the homeless, the forgotten and those in need. We must seek truth and social justice. These are the principles and values by which we shall govern. (SODELPA 2014c)

The posting goes on to say that all religious groups should be free to practice their faith without fear or intimidation and that the Christian values of the party makes it more sensitive to respecting the values of others, thus reflecting the idea that Fiji draws its strength from the rich variety of traditions, languages and cultures of its communities (SODELPA 2014c). This post received 79 'likes'. Evidently, this posting suggests some diversity in the views of the SODELPA membership, albeit, perhaps too liberal for the mainstay of the party as it no longer appears on the official SODELPA Facebook page. The views espoused here match the first part of the SODELPA manifesto (also available online), which claims it will guarantee:

- The freedom, equality and dignity of all individuals as fellow citizens,

- The freedom and dignity of all religions and religious denominations;

- The equality and dignity of all communities, their freedom to promote their languages and customary practices, and the protection through appropriate legislation of their cultural heritage and intellectual property ... (SODELPA 2014a, p. 5). 
However, the second part of the manifesto reverts to strongly nationalist Taukei interests, revealing a desire to reinstate the Great Council of Chiefs and the institutions for Taukei land. Clearly, the SODELPA leaders intended to focus on attaining the support of the nationalist Christian Taukei, but knew that would not be enough to win the elections.

As a government supporter, the Fiji Sun is known to be a vigilant critic of nationalist Taukei values. For instance, it reported that SODELPA member Semesa Karavaki proposed in Parliament that government should fund the teaching of the Ten Commandments in school, which, he argued, would end crime and all other social ills (Tuwere 2014). ${ }^{8}$ On the one hand, although reminiscent of the New Right in the USA, the notion of teaching the Ten Commandments in school is not terribly extreme for Taukei Christians, because meetings in government departments in Fiji have often begun with Christian prayers. On the other hand, if the secular state might choose to remove prayers and religious teaching from schools, there was another issue of concern for SODELPA. Many Taukei schools in Fiji are private, religious schools (Methodist, Catholic, SDA, Pentecostal, etc.). If the government enforced the secular state, it was feared that the government would also then enforce a secular curriculum in these religious schools (SODELPA 2014a), to which SODELPA was unequivocally opposed.

If SODELPA seemed to be promoting the nationalist Taukei vision of a Christian Fiji, members of the Bainimarama Government have also attracted accusations of religious and communal favouritism, contrary to its aim of providing equal opportunities across social and ethnic division. Allegations have included the question of whether the Attorney-General, Aiyaz Sayed-Khaiyum, took out massive loans to support his brother's move to head the Fiji Broadcasting Corporation (Lal 2012). Rumours also targeted Muslim businessmen, alleging they had roles in the coup (Bola-Bari 2014). Certainly, the government's

8 A further example of the extent to which Karavaki identifies with such values can be found in his video on YouTube, Noqu Kalou, Noqu Vanua, which opens with a graphic showing a red line being drawn from Israel directly to Fiji (Karavaki 2014), a reference to the narrative of the Kaunitoni Migration that claims Taukei travelled from somewhere in Africa, possibly from the Holy Lands, to Fiji by canoe, and which suggests that Karavaki identifies strongly with nationalist Taukei Methodism. 
post-election gift of FJD\$12,000 towards a Muslim priest's house in Labasa (Drauna 2015) ignored the way that public perception might construe such a gift in terms of religious and therefore racial bias.

In this way, the intention to increase the distance between church and state in Fiji has been fraught with difficulties because not only do many people share the view that religious institutions should represent their adherents but also because government representatives frequently belong to religious communities they feel obliged to support in patronclient styles of relationship, or at least are represented as doing so.

\section{Where the land ends and the sea begins ...}

Two years before the elections, the Fiji National Rugby League posted a message to Facebook that showed the extent to which the old maxims had retained their power. Simply by translating Noqu Kalou, Noqu Vanua as 'My God, my country' (Fiji National Rugby League 2012), the conception of the vanua was being used in such a way that its meaning had expanded from the description of a kin group the size of several villages to the borders of the nation-state.

Yet, the fact that SODELPA attracted less than 50 per cent of the Taukei vote in 2014 (Ratuva, this volume) suggests that the nationalist voice had been neutralised on the national stage quite effectively. Were Taukei voters turning away from SODELPA because of its support for Taukei institutions such as the Great Council of Chiefs and the protection of Taukei land, which is indicative of this nationalism? Certainly, the suggestion that increasing numbers of Taukei are rejecting nationalism has been posited as a reason for the Methodist Church of Fiji losing adherents (Weir 2015), but it is difficult to verify. The decline in Methodist Church numbers made the agenda of the 2014 conference, where it was recorded that membership had declined by 1,788 people in the year from 2013 to 2014 (Methodist Church in Fiji 2014). Although this is only a decline of 0.9 per cent (from 200,565 to 198,777 ), it appears that the Methodist Church is losing ground to other Christian denominations (Weir 2015). Yet, although Pentecostal churches offer profoundly different theologies to those of the Methodist Church, many retain conceptions of the paramountcy of the Taukei in the Fiji nation-state, Christianity's role in state affairs, and conservative forms of male leadership, Christian marriage 
and family. Therefore, conversion to Pentecostal Christianity is not by itself a convincing indicator that Taukei are rejecting the values underpinning nationalism.

A more likely reason for SODELPA's failure at the elections was that it reflected its failure to appeal to a broad section of the electorate. The manifesto Reclaiming Fiji attempts to channel and mobilise the resentments of all those who had been threatened and coerced since the military's takeover in 2006, including nationalist Taukei, Catholics, pro-democracy supporters, and feminist activists. However, this was a difficult, perhaps impossible, challenge because ultimately SODELPA's central party focus was to support the Taukei institutions of governance and land, which lie in opposition to other interests motivated by democracy and/or women's rights. Despite claims to the contrary, the nationalist vision excludes other races and other religious persuasions from holding full rights as equal citizens in nationhood. In addition, in spite of the fact that SODELPA's leader is a woman, the nationalist vision positions women without chiefly titles structurally as second to men at work and in their marital homes, and excludes homosexuals and transgender citizens. Further, even within the Taukei community that espouses nationalism, there are tensions about exactly what the ideal relationship between the vanua, lotu and matanitu should be (cf. Ryle 2010).

Taukei nationalism, whether in SODELPA or the Methodist Church, sits in opposition to what Weir calls 'universalism' (which, I would argue, refers to a liberal set of values, most of which originated in so-called Western countries) (Weir 2015). The inconsistencies in the SODELPA manifesto reflect the struggle among and between villagelevel notions of Methodism and international ideas of Methodism as they play out at the national level. However easy it is to support one side of the debate over the other, any solution for the Taukei community must lie, not in repression of the other side, but in a synthesis between indigenous and international ideas (in all their diversities) in a style particular to Fiji.

This is perhaps one of the undercurrents of a distinctive turn in current Methodist theology, away from the vanua and towards the moana, the ocean. From Epeli Hau' ofa's recasting of the Pacific Islands from specks in the sea to 'a sea of islands' (Hau' ofa 2008) to a rising interest in the 
Pacific-designed and built double-hulled sailing boat or drua, ${ }^{9}$ and the realisation that Pacific Islanders must face the destruction created by rising sea levels and climate change (Halapua 2008), theologians from many of the Pacific mainline churches are now turning to remembrances of the early sailors and their navigation of the ocean for new possibilities of hope and pride.

\section{The new Exodus of the Methodist Church of Fiji}

Central to the nationalist rhetoric was the notion that Fijians were like the Hebrews cast from their lands as depicted in Exodus and Jeremiah. ${ }^{10}$ As President-elect of the Methodist Church of Fiji, Banivanua continued using these ideas, but central to his conception of the new Exodus facing the Methodist Church of Fiji is a sense of reflection:

Moses speaks to the people of Israel as they prepare to enter the 'Promised Land' and asks them to look back at their 40-year journey through the wilderness and from being a rag-tag group of oppressed people to becoming a nation on the move, people who have made a collective covenant with God. (Banivanua 2014b)

After taking office as the President of the Methodist Church of Fiji in January 2015, Banivanua's ideas about the church's new exodus, $\mathrm{Na}$ Lako Yani Vou, were further elaborated at a meeting a couple of months later:

For me one of the main questions that we should ask was: Why did God allow this to happen to a church that God had called to bring Christianity to this land in 1835 ?

Like that pre-Exodus time, the Israelites were going through very difficult times at the hands of the Egyptians. Likewise in the preBabylonian exile period the Jewish people went through some very difficult times as well. Both these events were going on without the full knowledge of the Israelites of God's intention.

9 For example, seven drua were built in Auckland, New Zealand, for different trusts around the Pacific to encourage Pacific Islanders to continue or to revive their traditional boatbuilding and navigational skills (Pacific Voyagers n.d.)

10 See Newland 2015 for the development of this rhetoric. 
I believe that the same situation, faced by Israelites in the Exodus and after the Exile, is now faced by the Methodist Church in Fiji. (Baghwan 2015)

Here, Banivanua is appealing to the same community who felt they were losing their place in the nation-state in 1987 and 2000, but he consistently uses the notion of Exodus to reflect on the changes that need to come about in the Methodist Church, saying, 'the time had come to do some reordering of society and help people called Methodists in Fiji to renew, recreate, reinvent and rebuild, God's church' (Baghwan 2015). Central to this vision is ecumenism between Christian churches and building relationships with the Hindu and Muslim communities. He focuses on restoring 'a right relationship between us and God, a relationship based on love. The Methodist Church's building of relationships is part and parcel of our new journey, the Lako Yani Vou. It is part of our calling' (Baghwan 2015).

As part of this revised rhetoric, Banivanua introduces a new concept of an inclusive vanua:

In this process of rebuilding relationships, the church's relationship with the vanua continues to be one we value and need to strengthen ...

At the same time we are called to practise love in a radical way that impacts the vanua. As Christian Fijians we need to be inclusive our understanding of the vanua to include all the other ethnic groups that live in the vanua.

My vision is that the Methodist Church's relationship-building process must be one that engages not only with government or a certain community but engages with everybody in Fiji. (Baghwan 2015)

In adapting some of the nationalist language to his own rhetoric, Banivanua is attempting to write over previous ideas of exclusiveness, to appropriate nationalist language in a different direction while (re-)creating a vision that Methodist adherents can identify with. At the same time, it is a more inclusive vision that attempts to unify the rural, the urban and the international notions of Methodism. While Banivanua's vision of the new Exodus redefines the vanua as multiracial and multi-religious, extending beyond the Taukei, the vanua is still grounded firmly in Taukei conceptions of the world. 
However, it is a stride away from the ethno-religious nationalism of the coups in 1987 and 2000, and of the government's policies prior to the 2006 coup.

How convincing Banivanua is to the adherents of the Methodist Church of Fiji is yet to be seen. Given the postings on the Methodist Church's blogsite, there remain tensions within the church about teachings with regard to homosexuality and family form. This indicates that, although it might appear that the Methodist Church has been transformed, coming to a consensus on how the church community can suitably relate to the wider world may be more complicated. The new Exodus, then, is a fragile process.

In another shift in theology, if the land is still in sight, it is no longer the place from which decisions are made:

The drua is ready, the map is ready, the winds are blowing. All that is needed now is for the crew to commit to the journey and follow their captain in this bold journey. (Baghwan 2015)

Again, the use of old images and language in this way is a tentative one. While drawing on the romance of the drua, the ocean-based journey has been used by nationalist Methodist clans in the Kaunitoni Migration, the narratives that talk of ancestors arriving from foreign lands by sea in canoes. Can the redeployment of this imagery erase and/or redirect the old meanings? Is a theology of the ocean already too reminiscent of other interests or does it represent the hope of new directions?

\section{Acknowledgements}

This paper was written at the University of St Andrews, which provides a considerable distance for my own reflection on the nine years I spent lecturing out of the University of the South Pacific in Fiji, during which I experienced the atmosphere of Suva for a year in 2001 and from 2005 until 2012. Thanks to Steven Ratuva for giving me this opportunity to reflect on more recent events. 


\section{References}

Baghwan, James 2015, 'Let's mend bridges', Fiji Times [Online], 11 March. Viewed 13 July 2015 at www.fijitimes.com/story. aspx?id=297753.

Baleiwaqa, Tevita 2003, Rerevaka na kalou ka doka na tui: Fear God and Honour the King: The Influence of the Wesleyan Methodists on the Institutions of Fijian Identity, Unpublished $\mathrm{PhD}$ thesis, The Australian National University, Canberra.

Banivanua, Tevita 2014a, 'Statement to the media', 25 September, methodistfiji.blogspot.com.au and on Facebook. Viewed 13 July 2015 at www.facebook.com/permalink.php?id=432821093498034 \&story_fbid=640634679383340.

Banivanua, Tevita 2014b, 'Fiji Day message', 7 October. Viewed 13 July 2015 at methodistfiji.blogspot.co.uk/search?updated-max=2014-1201 T22:22:00\%2B13:00\&max-results $=7 \&$ start $=7 \&$ by-date $=$ false.

Bola-Bari, Vuniwaqa 2014, 'Keep religion out, Sareem tells politicians', Fijilive. Viewed 13 July 2015 at fijilive.com/news/2014/07/keepreligion-out-sareem-tells-politicians/58414/.

Bolatiki, Maika 2013, 'Methodist Church says "no" to politics', Fiji Sun [Online], 21 June. Viewed 2 February 2015 at fijisun.com. $\mathrm{fj} / 2013 / 06 / 21 /$ methodist-church-says-no-to-politics/.

Bolatiki, Maika 2014, 'Church disappoints PM', Fiji Sun [Online] 25 September. Viewed 2 February 2015 at fijisun.com.fj/2014/09/25/ church-disappoints-pm/.

Chandar, Reginald 2013, 'Be responsible, religious leaders told', Fijilive, 21 September. Viewed 13 July 2015 at fijilive.com/.

Drauna, Peni 2015, 'New Quarters For Priest', Fiji Sun [Online], 7 January. Viewed 2 February 2015 at fijisun.com.fj/2015/01/07/ new-quarters-for-priest/.

Ernst, Manfred 2004, Winds of change: Rapidly growing religious groups of the Pacific Islands, Pacific Conference of Churches, Suva. 
Fiji Bureau of Statistics 2007, 'Census of Population and Housing'. Viewed 2 February 2015 at www.statsfiji.gov.fj/index.php/2007census-of-population.

Fijilive 2014, 'Women, church cautioned ahead of election', 9 September. Viewed 29 November 2015 at fijilive.com/m/ newsdetails.php?cat $=1$ \&id $=58878$.

Fiji National Rugby League 2012, [Facebook Post] 8 June. Viewed 13 July 2015 at www.facebook.com/Fijibati/posts/159707494161503.

Garrett, J 1990, 'Uncertain sequel: The social and religious scene in Fiji since the coups', The Contemporary Pacific, vol. 2, no. 1, pp. 87-111.

Halapua, Winston 2003, Tradition, lotu, and militarism in Fiji, Fiji Institute of Applied Studies, Nadi.

Halapua, Winston 2008, 'Moana methodology: A way of promoting dynamic leadership', Talanoa Oceania. Available at sites.google. com/a/nomoa.com/talanoa/Home/papers-presentations/halapuamoana.

Hau'ofa, Epeli 2008, 'Our sea of islands', in E Hau' ofa, We are the ocean: Selected works, University of Hawaii Press, Hawai'i.

Kant, Romitesh and Rakuita, Eroni 2014, Public participation \& constitution-making in Fiji: A critique of the 2012 constitutionmaking process, State, Society and Governance in Melanesia Discussion Paper 2014/6, pp. 1-19. Viewed 2 February 2015 at digitalcollections.anu.edu.au/bitstream/1885/12254/1/Kant\%20 $\% 26 \% 20$ Rakuita \%20Public \%20participation \%202014.pdf.

Karavaki, Semesa Druavesi 2014, Noqu Kalou, Noqu Vanua, 7 September. Viewed 2 February 2015 at www.youtube.com/ watch? $\mathrm{v}=\mathrm{k}-\mathrm{xk} 6 \mathrm{i} 2 \mathrm{eeIA}$.

Kate, Talebula 2014, 'Court told of the Reverend Waqairatu's death', Fiji Sun [Online], 19 February. Viewed 2 February 2015 at fijisun. com.fj/2014/02/19/court-told-of-the-reverend-waqairatus-death/.

Kelly, Charlotte 1945, 'The Catholic Church in Fiji 1844-1944', An Irish Quarterly Review, vol. 34, no. 135, pp. 361-68. 
Lal, Victor 2012, 'The Kaiyyum's \$22 million bank loan to set up FBC TV', Coupfourpointfive, 1 July. Viewed 2 February 2015 at www. coupfourandahalf.com/2012/07/khaiyums-22million-bank-loanto-set-up.html.

Methodist Church in Fiji 2014, Resolutions from the 2014 Conference. Viewed 13 July 2015 at www.methodistfiji.org/2014-conferenceresolutions.html.

Narsey, Wadan 2013, 'Why the Fiji regime rejected the draft constitution', in Sam Roggeveen (ed.), The Interpreter, Lowy Institute for National Policy, Sydney. Viewed 2 February 2015 at www.lowyinterpreter.org/post/2013/01/15/Why-the-Fiji-regimerejected-the-draft-constitution.aspx?COLLCC $=4154162473 \&$.

Newland, Lynda 2006, 'Fiji', in Manfred Ernst (ed.), Globalization and the re-shaping of Christianity in the Pacific Islands. The Pacific Theological College, Suva, pp. 317-89.

Newland, Lynda 2007, 'The role of the Assembly of Christian Churches in Fiji (ACCF) in the 2006 elections', in Jon Fraenkel and Stewart Firth (eds), From election to coup in Fiji: The 2006 campaign and its aftermath, ANU E Press and Asia Pacific Press, Canberra. Available at: epress.anu.edu.au/wp-content/uploads/2011/05/ch23.pdf.

Newland, Lynda 2009, 'Religion and politics: The Christian churches and the 2006 coup in Fiji', in Jon Fraenkel, Stewart Firth and Brij V Lal (eds), The 2006 military takeover in Fiji: A coup to end all coups? ANU E Press, Canberra. Available at: epress.anu.edu.au/wpcontent/uploads/2011/02/ch091.pdf.

Newland, Lynda 2012, 'New Methodism and old: Churches, police and state in Fiji, 2008-09'. The Round Table: The Commonwealth Journal of International Affairs, Special Edition, vol. 101, no. 6, pp. 537-55.

Newland, Lynda 2013, 'Imagining nationhood: narratives of belonging and the question of a Christian state in Fiji', Global Change, Peace \& Security: formerly Pacifica Review: Peace, Security \& Global Change, DOI:10.1080/14781158.2013.784247. 
Newland, Lynda 2015, 'The lost tribes of Israel - and the genesis of Christianity in Fiji: Missionary notions of Fijian origin from 1835 to cession and beyond', Oceania, Special Edition, Lynda Newland and Terry Brown (eds), vol. 85, no. 3, pp. 256-70.

Niukula, Paula 1994, The three pillars: The triple aspect of Fijian society, Christian Writing Project, Suva.

Pacific Voyagers n.d., 'General Overview', Pacific Voyagers. Viewed 13 July 2015 at pacificvoyagers.org/vaka-moana/.

Radio New Zealand 2014, 'Fiji's Methodist Church takes new approach', 27 August. Viewed 13 July 2015 at www.radionz. co.nz/international/programmes/datelinepacific/audio/20147334/ fiji \%27s-methodist-church-takes-news-approach.

Rasoqosoqo, Losalini 2013, 'Strong stand: Church warns ministers about politics, coups', Fiji Sun [Online], 29 August. Viewed 2 February 2015 at fijisun.com.fj/2013/08/29/strong-stand/.

Rasoqosoqo, Losalini 2014, 'Reverend Waqairatu dies aged 66', Fiji Sun [Online], 12 February. Viewed 2 February 2015 at fijisun. com.fj/2014/02/12/reverend-waqairatu-dies-aged-66/.

Ryle, Jacqueline 2010, My God, My land: Interwoven paths of Christianity and tradition in Fiji, Ashgate Publishing Co, Surrey and Burlington.

SODELPA 2014a, Reclaiming Fiji: The Manifesto of Sodelpa. Viewed 2 February 2015 at sodelpa.org/SODELPA-manifesto-LR.pdf.

SODELPA, 2014b, [Facebook Post], 18 July. Viewed 2 February 2015 at www.facebook.com/sodelpa/posts/1397324750488161.

SODELPA, 2014c, 'Statement No 21: SODELPA's position on matters misrepresented by the media'. Viewed 2 February 2015 at fijitoday. wordpress.com/2014/08/22/statement-no-21 sodelpas-position-onmatters-misrepresented-by-the-media/ and Viewed 2 February 2015 on Facebook at www.facebook.com/707325785971101/photos/a.70 7329135970766.1073741828.707325785971101/731218353581844/.

Sopepa, Nikotemo 2014, [Facebook Comment]. Viewed 2 February 2015 at www.facebook.com/permalink.php?id=432821093498034 \&story_fbid=640634679383340. 
Swami, Nasik 2014, 'Think before you vote', The Fiji Times [Online], 18 July. Viewed 13 July 2015 at www.fijitimes.com/story.aspx? $\mathrm{id}=274655$.

Talebula, Wati 2014, 'New Methodist president in August', Fiji Sun [Online], 9 May. Viewed 2 February 2015 at fijisun.com. fj/2014/05/09/new-methodist-president-in-august/.

Taleitaki, Siteri 2014, 'New Methodists rally in the north nation needs god for the betterment of its people: Rev Vulaono' , Fiji Sun [Online], 28th April. Viewed 2 February 2015 at fijisun.com.fj/2014/04/28/ new-methodists-rally-in-the-north-nation-needs-god-for-thebetterment-of-its-people-rev-vulaono/.

Tawake, Salaseini 2013, 'Methodists: No politics', Fiji Sun [Online], 8 January. Viewed 2 February 2015 at fijisun.com.fj/2013/01/08/ methodists-no-politics/.

Tippett, Alan R 1980, Oral tradition and ethnohistory: The transformation of information and social values in early Christian Fiji 1835-1905, St Marks Library, Canberra.

Tomlinson, Matt 2006, 'Retheorizing mana: Bible translation and discourse of loss in Fiji', Oceania, vol. 76 no. 2, pp. 173-85.

Tuwere, Iliesa S 2002, Vanua: Towards a Fijian theology of place, Institute of Pacific Studies, University of the South Pacific and College of St John the Evangelist, Suva.

Tuwere, Josua 2014, 'Money for the church?' Fiji Sun [Online], 4 December. Viewed 2 February 2015 at fijisun.com.fj/2014/12/04/ money-for-church/.

Walmsley, Claire 1987, Paradise in Peril [Documentary], Reporter: Martin Young, BBC TV.

Weir, Christine 2015, 'The 2014 Fiji elections and the Methodist church', The Round Table: The Commonwealth Journal of International Affairs, vol. 104, no. 2, pp. 165-75. 
This text is taken from The People Have Spoken: The 2014 Elections in Fiji, edited by Steven Ratuva and Stephanie Lawson, published 2016 by ANU Press, The Australian National University, Canberra, Australia. 